\title{
Demystifying Critical Thinking through the Exploration of Social Media
}

\author{
Jay Tanaka Ph.D. \\ Research Faculty of Media and Communication, Hokkaido University \\ (D)/0000-0002-1579-0960 \\ DOI: https://dx.doi.org/10.46679/978819484836312
}

\section{Abstract}

Critical thinking is a term used to describe one of the aims of higher education programs around the world. As an example, the Council of Writing Program Administrators (2011) clearly lists critical thinking as one of five inherently desirable educational outcomes in post-secondary writing in the United States. However, the definition of critical thinking is complicated by a large variety of philosophical concepts and a lack of clarity as to what students should actually learn and do (Moore, 2013). Too often, university courses impose unclear expectations on students, which adds unnecessary difficulty, particularly for multilingual, multicultural, and international students, who might not be socialized into the use of critical thinking in academic work. (Robertson, et al., 2000; Tran, 2011). Even university instructors themselves admit to a lack of comprehensive understanding of critical thinking and how it can be taught (Hang, 2011). In so far as standards for critical thinking in academic work will be imposed on students, there is a need for a clarification of critical thinking, leading to practical directions for classroom instruction.

In this chapter, I propose a pedagogically focused definition for critical thinking and illustrate how this definition can be applied to a teaching approach involving the exploration and presentation of information on social media. It begins with an explanation to students regarding the epistemology of critical thinking, dispositions that support or deter its practice, and integrated skills. Adhering to this 
framework of critical thinking, students then explore a variety of comments on social media in order to deepen their understanding of social issues and of society itself. This approach to teaching critical thinking also provides a structure for academic presentations or written assignments that may serve as final products of the learning experience. The nature of student perspectives with regards to this approach to teaching critical thinking is also discussed.

Keywords: Multilogical thinking, Higher-order thinking, English for academic purposes, English for specific purposes, Academic writing, Academic presentation

\section{Introduction}

Critical thinking currently remains, in theory, and practice, a convoluted concept for both teachers and students in academic writing courses, despite it being an integral part of desirable outcomes. The definition of critical thinking is complicated by a large variety of philosophical concepts and a lack of clarity as to what students should actually learn and do (Moore, 2013). Unclear conceptions lead to unclear classroom practices, and it is unfair to impose a standard of critical thinking in the assessment of academic work without clearly delineating its structure to students. This is particularly true for students from cultures that do not validate critical thinking or have entirely different conceptions of critical thinking. Despite this lack of clarity in the classroom, critical thinking remains a salient and clearly documented goal of higher education institutions.

Works of academic writing, in the form of essays or research papers, are the traditional educational products of higher education, and so, naturally, expectations in academic writing are a focal point for expectations for critical thinking. In 2011, the Council of Writing Program Administrators (CWPA), the National Council of Teachers of English, and the National Writing Project solicited research and 


\section{This is a limited preview of the chapter.}

To read the full-text chapter, get access by purchasing this chapter or consider buying the complete book. If your library has subscription to EBSCOhost, the chapter including other chapters of the book can be accessed through your library.

This chapter is a part of the book, 'Development of Innovative Pedagogical Practices for a Modern Learning Experience' ISBN (paperback): 978-81948483-6-3; ISBN (ebook): 978-81-948483-7-0

Book DOI: https://dx.doi.org/10.46679/9788194848363

Available via CSMFL Bookstore, Amazon, Google Play Books, EBSCOhost \& EBSCO eBooks 
society, although it certainly has the potential for such aims. As mentioned previously, critical thinking is simply a tool for the exploration of possibilities and perspectives, a tool available for use toward any number of different goals. I suggest, then, that ideas within different schools of thought can provide direction for critical thinking's use toward specific purposes.

Finally, although I have defined critical thinking as the exploration of possibilities and perspectives to tailor it toward clear application in educational contexts, it is important to note that the larger concept of critical thinking instruction necessarily entails much more than this - namely, instruction in deductive reasoning. The thinking skills required to discern inaccuracies and falsehoods, solve problems, and provide appropriate evidence are invaluable to the holistic process of critical thinking. However, these thinking skills alone do not assure students an escape from non-critical reductive thinking. "Skillfully" discerning inaccuracies and falsehoods, if from a monological perspective, only serves to strengthen bigotry. Thus, I argue that critical thinking instruction should focus on exploratory and expansive thought, providing educators with a manageable set of practical teaching points that clearly distinguishes critical thinking from non-critical, reductive thinking. Explaining this distinction clearly is of the utmost importance when requiring critical thinking in academic courses. As teachers, it is our responsibility to explicitly communicate our expectations regarding critical thinking and our reasons for teaching it.

\section{References}

Alnofaie, H. (2013). A framework for implementing critical thinking as a language pedagogy in EFL preparatory programmes. Thinking Skills and Creativity, 10, 154-158.

doi:http://dx.doi.org/10.1016/j.tsc.2013.09.002 
Atkinson, D. (1997). A critical approach to critical thinking in TESOL. TESOL Quarterly, 31(1), 71-94. doi:10.2307/3587975

Benesch, S. (1993). Critical thinking: A learning process for democracy. TESOL Quarterly, 27(3), 545-548. doi:10.2307/3587485

Burbules, N. C., \& Berk, R. (1999). Critical thinking and critical pedagogy: Relations, differences, and limits. In T. S. Popkewitz \& L. Fendler (Eds.), Critical theories in education (pp. 45-65). Routledge.

Burns, A. (2017). Envoi: From reflective practice to action research? In R. Barnard \& J. Ryan (Eds.), Reflective practice: Voices from the field. Routledge.

Burns, A., \& Richards, J. C. (2009). The Cambridge guide to second language teacher education. Cambridge University Press.

Council of Writing Program Administrators, National Council of Teachers of English, \& National Writing Project. (2011). Framework for success in postsecondary writing. Retrieved from http://wpacouncil.org/files/framework-for-successpostsecondary-writing.pdf

Davidson, B. W. (1998). Comments on Dwight Atkinson's “A critical approach to critical thinking in TESOL": A case for critical thinking in the English language classroom. TESOL Quarterly, 32(1), 119-123. doi:http://dx.doi.org/10.2307/3587906

Ennis, R. H. (1985). A logical basis for measuring critical thinking skills. Educational Leadership, 43(2), 44-48.

Ennis, R. H. (1989). Critical thinking and subject specificity: Clarification and needed research. Educational researcher, 18(3), 4-10. doi:http://dx.doi.org/10.3102/0013189X018003004

Facione, P. A. (1990). Critical thinking: A statement of expert consensus for purposes of educational assessment and instruction. Research findings and recommendations. American Philosophical Association. 
Fischer, S. C., Spiker, V. A., \& Riedel, S. L. (2009). Critical thinking training for Army officers. Volume 2: A model of critical thinking. U.S. Army Research Institute for the Behavioral and Social Sciences.

Halpern, D. F. (2014). Thought and knowledge: An introduction to critical thinking. Psychology Press.

Hang, D. B. (2011). Staff perceptions about the role of writing in developing critical thinking in business students. In P. Le Ha \& B. Baurain (Eds.), Voices, identities, negotiations, and conflicts: Writing academic English across cultures (Vol. 22, pp. 75-98). Emerald Group Publishing.

Holliday, A., Hyde, M., \& Kullman, J. (2010). Intercultural communication: An advanced resource book for students. Routledge.

Hyland, K. (2004). Disciplinary discourses: Social interactions in academic writing. University of Michigan Press.

Hyland, K. (2005). Stance and engagement: A model of interaction in academic discourse. Discourse Studies, 7(2), 173-192. doi:10.1177/1461445605050365

Hyland, K., \& Tse, P. (2004). Metadiscourse in academic writing: A reappraisal. Applied Linguistics, 25(2), 156-177. doi:10.1093/applin/25.2.156

Jay, J. K., \& Johnson, K. L. (2002). Capturing complexity: A typology of reflective practice for teacher education. Teaching and Teacher Education, 18(1), 73-85. doi:10.1016/S0742-051X(01)00051-8

Kahneman, D. (2011). Thinking, fast and slow. Farrar, Straus and Giroux. Kuhn, D. (1999). A developmental model of critical thinking. Educational researcher, 28(2), 16-46. doi:http://dx.doi.org/10.3102/0013189X028002016

Laurillard, D. (2012). Teaching as a design science: Building pedagogical patterns for learning and technology (1st ed.). Routledge.

Levy, D. A. (2010). Tools of critical thinking: Metathoughts for psychology. Waveland Press. 
Lipman, M. (1988). Critical thinking: What can it be? Educational Leadership, 46(1), 38-43.

McKinley, J. (2013). Displaying critical thinking in EFL academic writing: A discussion of Japanese to English contrastive rhetoric. RELC Journal, 44(2), 195-208. doi:10.1177/0033688213488386

McPeck, J. (1981). Critical thinking and education. St. Martins.

McPeck, J. (1992). Thoughts on subject specificity. In S. P. Norris (Ed.), The generalizability of critical thinking: Multiple perspectives on an educational ideal(pp. 198-205).Teachers College Press.

Mill, J. S. (1860/1999). On liberty. Broadview Press.

Moore, T. (2013). Critical thinking: Seven definitions in search of a concept. Studies in Higher Education, 38(4), 506-522. doi:10.1080/03075079.2011.586995

Norris, S. P. (1985). Synthesis of research on critical thinking. Educational Leadership, 42(8), 40-45.

Norris, S. P. (1992). The generalizability of critical thinking: Multiple perspectives on an educational ideal. Teachers College Press.

Owens, L. M. D., \& Kadakia, C. (2020). Designing for modern learning: Beyond ADDIE and SAM. Association for Talent Development.

Paul, R. (1984a). Critical thinking: Fundamental to education for a free society. Educational Leadership, 42(1), 4-14.

Paul, R. (1984b). Teaching critical thinking in the "strong" sense: A focus on self-deception, world views, and a dialectical mode of analysis. Informal Logic, 4(2), 2-7.

Paul, R. (1995). Critical thinking: How to prepare students for a rapidly changing world. Foundation for Critical Thinking.

Paul, R. (2005). The state of critical thinking today. New Directions for Community Colleges, 2005(130), 27-38. doi:http://dx.doi.org/10.1002/cc.193

Paul, R., \& Elder, L. (2007). Critical thinking: The art of socratic questioning. Journal of Developmental Education, 31(1), 36-37. Retrieved from https://www.jstor.org/stable/42775632 
Robertson, M., Line, M., Jones, S., \& Thomas, S. (2000). International students, learning environments and perceptions: A case study using the Delphi technique. Higher Education Research \& Development, 19(1), 89-102.

Schreier, M. (2012). Qualitative content analysis in practice. Los Angeles: SAGE.

Siegel, H. (1992). The generalizability of critical thinking skills, dispositions, and epistemology. In S. P. Norris (Ed.), The generalizability of critical thinking: Multiple perspectives on an educational ideal(pp. 97-108). Teachers College Press.

Stapleton, P. (2002). Critical thinking in Japanese L2 writing: rethinking tired constructs. ELT Journal, 56(3), 250-257. doi:10.1093/elt/56.3.250

Swales, J. (1990). Genre analysis: English in academic and research settings. Cambridge University Press.

Tanaka, J., \& Gilliland, B. (2017). Critical thinking instruction in English for academic purposes writing courses: A dialectical thinking approach. TESOL Journal, 8(3), 657-674. doi:10.1002/tesj.291

Thompson, G. (2001). Interaction in academic writing: Learning to argue with the reader. Applied Linguistics, 22(1), 58-78. doi:10.1093/applin/22.1.58

Tran, L. T. (2011). Turning the spotlight to international students' internal negotiations: Critical thinking in academic writing. In P. Le Ha \& B. Baurain (Eds.), Voices, identities, negotiations, and conflicts: Writing academic English across cultures (Vol. 22, pp. 5974). Emerald Group Publishing.

Vyncke, M. (2012). The concept and practice of critical thinking in academic writing: An investigation of international students' perceptions and writing experiences. [Master's Thesis, King's College]. Retrieved from https://www.teachingenglish.org.uk/sites/teacheng/files/m_vy ncke_0_1.pdf 
Yang, Y.-T. C., \& Gamble, J. (2013). Effective and practical critical thinking-enhanced EFL instruction. ELT Journal, 67(4), 398-412. doi:http://dx.doi.org/10.1093/elt/cct038

\begin{abstract}
About the author
Jay Tanaka is a specially appointed associate professor at Hokkaido University. He completed his $\mathrm{PhD}$ in second language studies at the University of Hawai' $i$ at Mānoa. His research interests are in second language pedagogy, reflection in language teacher education, and critical thinking instruction.
\end{abstract}

